\title{
ENVIRONMENTAL CONTINGENCIES AND SUSTAINABLE MODES OF CORPORATE GOVERNANCE
}

\author{
Neil Garrod \\ Department of Accounting and Finance \\ University of Glasgow \\ 65-71 Southpark Avenue \\ Glasgow G12 8LE
}

Scotland.

Comments by Clive Emmanuel and participants at the International Conference, Faculty of Economics, University of Ljubljana, September 1996 are gratefully acknowledged. All views 
expressed and any remaining errors are those of the author. 


\title{
ENVIRONMENTAL CONTINGENCIES AND SUSTAINABLE MODES OF CORPORATE GOVERNANCE
}

\begin{abstract}
The corporate governance issue has received significant attention recently at both the academic and the regulatory levels. However, there is still no generally accepted definition of the term, consensus about what it means or common system of ensuring good practice. For the emerging economies of central and eastern Europe this lack of consensus creates yet another uncertainty on their road to a market economy. In this paper alternative models of corporate governance that have emerged in market-oriented economies are described and the critical determinants or contingencies of these different forms of governance identified. To illustrate the relationship between environmental and institutional contingencies and sustainable modes of governance, particularly for emerging economies, the case of Slovenija is described where aspects of three different western governance models have been adopted without due consideration of the exogenous factors required for their effective application.
\end{abstract}




\section{ENVIRONMENTAL CONTINGENCIES AND SUSTAINABLE MODES OF EFFECTIVE CORPORATE GOVERNANCE}

\section{Introduction}

The focus of this paper is the development of effective and suatainable corporate governance structures in general and for the transitional economies of central and eastern Europe in particular. The corporate governance is sue itself has received significant attention recently in the historically market based economies at both the academic ( witness the special edition of Accounting and Business Research, 1993 and the creation of a new journal, Journal of Corporate Governance, in 1993) and the regulatory (Cadbury, 1992) levels. However, there is still no generally accepted definition of the term nor consensus about what it means (Lawrence, 1994). Some define corporate governance from a legal perspective ( see e.g. Sheikh and Chatterjee, 1995), some from a shareholder perspective ( see e.g. Dimsdale, 1994; Cadbury, 1992) and yet others from a stakeholder perspective ( see e.g. Tricker, 1984, 1993). In the transitional economies of central and eastern Europe it is even used as shorthand for effective management performance evaluation (Vasilev, 1996).

Similar diversity is to be found in corporate governance mechanis ms in historically market based economies (see e.g. Monks and Minow, 1995). In the transitional economies of central and eastern Europe hybrid systems are developing which reflect different cocktails of the systems found in the market oriented economies of the USA, the UK and Germany. To provide a framework for the subsequent analysis, the critical environmental and institutional contingencies which moderate the effectiveness of these three systems are considered in Section II.

Given the current flux in which the emerging economies find most, if not all, of their environmental and institutional frameworks a broadly defined concept of corporate governance is developed for use in Section III where a critique of the current corporate governance environment in one of the transitional economies, Slovenija, is developed. A model of the development and change process of corporate governance systems and the related environmental contingencies in the transitional economies is developed in Section IV. Concluding remarks are made in Section IV. 


\section{Concepts of Corporate Governance}

Monks and Minow (1995), amongst others, highlight the diversity of corporate governance in the historically market based economies. A rudimentary, but nonetheless useful, dichotomy of corporate governance systems is between the 'outsider' systems of the UK and USA and the 'insider' systems of Japan and Germany.

\section{II.1. 'Outsider' Systems}

In the 'outsider' system, corporate governance is ensured by the market for corporate control. Monks and Minnow (ibid.) list the conditions required for this system to be effective as:

- a large number of listed companies

- a liquid capital market where ownership and control rights are frequently traded

- few intercorporate equity holdings.

In an economic environment of this sort, issues of governance are dominated by the separation of ownership and management. Although the agency problems associated with this separation have been recognised since the time of Adam Smith, Berle and Means (1932) reinterpret this problem as the separation of ownership and control. In more recent work (see e.g. Manne, 1965; Alchian and Demsetz, 1972; Fama and Jensen, 1983) attempts have been made to identify potential mechanisms in this outsider system that might limit the agency problems that can arise from such a separation. These mechanisms include monitoring and control by non-executive directors and the design of suitable incentive mechanisms, but the ultimate sanction which enables these mechanisms to be effective is the market for corporate control itself.

\section{II.1.a. The US System}

US securities markets are characterised by all three of the necessary conditions identified by Monks and Minnow: 
- the New York Stock Exchange has over 2,900 company securities listed (London Stock Exchange, 1997)

- NYSE annual turnover of over L2,389 billion (London Stock Exchange, 1997)

- in 1994 non-institutional shareholders held over 55\% of securities (New York Stock Exchange, 1995, pp. 27).

Thus, in the US environment the market in corporate control, manifest in the takeover market, is likely to dominate all other mechanisms of corporate governance (Franks and Mayer, 1992b). Critically, corporate control, ownership changes and the resulting ownership structures are brought about via transparent equity trades in liquid security markets.

Scharfstein (1988) has set out the theory as to how informed raiders can assist shareholders in distinguishing between poor management performance and an unfavourable external economic environment, whilst a more practical expose of this market based approach to corporate governance is provided by the Economist (1994) which characterises the ideal system as one which:

.... would, first, give a boss enough freedom to manage well. It would ensure that he (sic) uses that freedom to manage the firm in the interests of shareholders. And, if someone else could do a better job, it would let him (sic). In such a system, the boss would know what the shareholders expected; and shareholders would have enough information to judge whether their expectations were being met and the power to act decisively if they were not. The system would keep shareholders sufficiently distinct from managers to let them buy and sell freely without breaching rules against insider trading in stockmarkets; a key virtue of the public company is that it gives investors liquidity.

However, the proportion of individual shareholders in the US has fallen over the past 40 years and progressive institutionalisation has been the dominant ongoing change in US share ownership since W orld W ar II (Friedman, 1996). Nonetheles s, the US market is still the largest and most diversley held market in the world with over 50 million individual shareholders and more than 10,000 institutional investors (Grasso, 1995). In addition, much of the institutional growth has been concentrated in the private pension funds with $401(\mathrm{k})$ plans dominating the market since the early to 
mid 1980s. These plans place the investment decision directly in the hands of individuals and thus the apparent institutionalisation is somewhat over stated (Friedman, 1996). Despite these changes in the US market, Friedman (1996) argues that the governance relevance of the market for corporate control has been strenghened by the move to greater institutional ownership.

\section{II.1.b. The UK System}

Whilst the UK market is also characterised by a large number of listings - 2,956 in 1996 - (London Stock Exchange, 1997) and high volume - LSE turnover of over L889 billion in 1996 - (London Stock Exchange, 1997), ownership structures are quite different to those in the US. Personal investment is at a much lower level (18\% in 1995 , Stock Exchange Quarterly, 1995) whilst institutional holdings (excluding banks) are much higher (62\% in 1995, London Stock Exchange, 1995). In addition, whilst the number of individual shareholders on the New York market is about five times that of the London market, the equivalent ratio for institutional investors is around 30 (London Stock Exchange, 1997). Thus the relative power of the institutional investor in the London market is much greater than in New York.

This smaller number of more powerful shareholders means that company shareholder relations are of a much more direct nature in the UK than in the takeover based market of the US (Holland, 1995). Typically institutional investors attempt to build a long term relationship with their investee companies with only a limited number of 'tradable' shares (Holland, 1996). Only if the relationship breaks down are disinvestment decisions taken. Indeed, empirical evidence from Franks and Mayer (1992a) indicates that takeovers are just one extreme on the continuum of corporate restructuring and Jenkins on and Mayer (1992) suggest that there is more evidence of an as sociation between poor corporate performance and direct institutional intervention than between poor performance and hostile takeovers in the UK. They go on to develop their argument that takeovers do, in fact, occur in the absence of any evidence of past poor performance in the expectation of the acquiring firm implementing a superior policy in the future.

Following the publication of the Cadbury Report (1992) the concept of corporate governance in the UK has been dominated by issues regarding the shareholder-director relationship. The focus of 
ensuring effective governance has been the structure of Boards of Directors and their subcommittees. Principally there is seen to be a major role for non executive directors and for the separation of the roles of chief executive and company chairman. This emphas is is curiously British in that it calls for professional self regulation of a Board of Directors which is not required under UK company law ${ }^{1}$ and for an increase in the number and influence of non-executive directors, whose powers and responsibilities are not differentiated in the Companies Acts (1985 and 1989) from those of executive directors. Thus much greater emphasis is placed on professional self regulation and private institutional shareholder-company communication than is the case in a market dominated by the takeover threat.

\section{II.2. Insider Systems}

\section{The German System}

Corporate governance in Germany reflects a very different style. In contrast to the Anglo-American system it relies in large part on monitoring by committee rather than competition through markets. These committees derive from the two-tier or dual board system (see e.g. Baums, 1993 and Ordelheide and Pfaff, 1994) and ownership structures. For companies with more than 500 employees the dual board system consists of a supervisory board, whose members are elected by the shareholders or, for companies with more than 2000 employees, a board where half of the members are elected by the shareholders and the other half by the employees and labour unions; and a management board which is appointed, usually, for a five year period by the supervisory board. Despite the appointment of the management board by the supervisory board the day to day management decisions involved in running the firm are taken by the former and the German system is characterised by a high degree of discretion granted to management. Only where management is clearly revealed to be unsuitable does direct intervention by the supervisory board occur (Franks and Mayer, 1992b).

${ }^{1}$ Section 282 of the 1985 Companies Act requires that each registered company shall have at least two directors but there is no requirement for these directors to constitute a board of directors'. 
Ownership structures also reveal a very different pattern to those found in 'outsider' system economies. In Germany, in 1995, only $17 \%$ of company shares were in the hands of individuals, $10 \%$ in the hands of banks but $42 \%$ in the hands of other companies (London Stock Exchange, 1995). Whilst many individuals deposit their shares and their voting rights with banks, so increasing their significance, it is the cross company holdings which dominates the nature of the insider system.

\section{II.3. 'Cocktail' Systems}

The historical links and current political and economic pressures on the transitional economies of central and eastern Europe mean that countries in the region have adopted different aspects of the institutional frameworks from several sources. Predominantly these are from the German (historical), UK (political) and USA (economic) systems.

The German system explicitly recognises some of the multiple interest groups (owner, lender, employee) affected by issues of governance. Even in the 'outsider' systems the idea of extending the concept of corporate governance beyond company (shareholder) performance is not new. Berle and Means (1932) identify the nature of modern corporations as social as well as economic institutions in which corporate managers assume new powers and responsibilities towards not only the shareholders but also to other stakeholders including employees, consumers, creditors, suppliers and the general community. Tricker (1993) pursues this concept of wider stakeholders but the stakeholder concept itself is ill defined and somewhat nebulous. Perhaps more importantly for the economies of central and eastern Europe it is also a static concept which allows little scope for changing or overlapping stakeholder groups (see e.g. Sheikh and Rees, 1995). In the context of ownership patterns emanating from privatisation schemes in these economies where many companies are manager/worker owned this static concept of the stakeholder is not helpful when considering appropriate governance mechanisms for economies, themselves, in transition.

Whilst a 'cocktail' approach to corporate governance might seem sensible as an operational implementation of the contingency approach suggested by Franks and Mayer (1992b,1996), as indicated above, the ultimate effectiveness of such a system depends crucially on the institutional structures in which the system operates. The US model highlights the importance of the operational 
nature, structure and operation of securities markets and the flow of information to them; the UK model underscores the importance of self regulatory management and professional controls; whilst the German system relies largely on a clearly defined legal and organisational structure within which control is effected.

Similar environmental contingencies have been identified for the regulation of financial reporting (Puxty et.al., 1987) Based on the work of Streeck and Schmitter (1985), they developed a theoretical framework in which regulation can be place on a continuum from 'liberalism', at one extreme, through 'associationism' and 'corporatism' to 'legalism' at the other. Their analysis places the USA as having elements of legalsim and associationism, with the latter subordinated to the former, the UK as principally as sociationist and Germany as predominantly legalist. These characterisations are developed from limiting and ideal cases of regulation, namely: the 'market', the 'state', and the 'community'. Building on the same framework, the working definition of corporate governance used in the subsequent analysis will encompass aspects of all three limiting cases.

1. accounting, auditing and financial reporting (market)

2. company law and management structure (state)

3. ownership structure and sources of capital (community)

\section{Corporate Governance in Slovenija}

Slovenija is an interesting case to consider as it has developed a comprehensive corporate governance environment which displays aspects of the UK, the US and the German systems. The accounting, reporting and auditing environment is largely modelled on the UK system, stock market regulation follows the US SEC model whilst company law is heavily influenced by the German company code. At first blush this system might appear both understandable to outsiders (i.e. potential western investors) and comprehensive. However, closer inspection raises questions about the effectiveness of the constraints imposed by these systems in the existing corporate environment in Slovenija. In many instances the underlying environmental factors required for these various measures to be effective are missing. As a consequence the apparent completeness of the Slovene corporate governance structure disguises considerable gaps which leave managers free to operate 
independently of other stakeholders and potentially constrain the transition to a market economy itself.

The three broad areas of corporate governance identified above will be considered in turn to illustrate the problems associated with the utilisation of corporate governance systems without the requisite institutional framework to make such systems effective.

\section{III.1 Accounting, Auditing and Financial Reporting}

In the two years following independence the Slovene accounting profession (spearheaded by a single accounting academic) produced 32 standards. The process was undoubtedly helped by preparatory work which had been taking place under the Yugoslav regime culminating in the adoption of a Code of Accounting Principles in 1989 upon which the Slovene standards were based (Garrod and Turk, 1996). Whilst the coverage of the standards is designed to comply with International Accounting Standards as much as possible, Slovenija's aspirations to join the EU mean that the standards are primarily modelled on UK regulation with EU 4th Directive overtones.

The standards are based on the user perspective (Preface to Slovene Accounting Standards pp. 1, 1993), as in the UK and USA. Whilst recognising multiple users, this perspective assumes that the information needs of investors underlie the information needs of all other users. Thus the primary focus of accounting reports is to provide useful information for security market decisions. Given a sophisticated securities market the participants are in a position to evaluate, to a certain extent, the operational definitions used by companies of such things as assets and liabilities. In the Slovene context this is not the case. The majority of Slovene companies are not publicly traded and the securities market itself is only slowly coming to terms with the information content of accounting numbers. This means that the necessary critical external evaluation of reporting regulation and practices is largely missing in Slovenija. Along with the very thin trading carried out on the Ljubljana Stock Exchange (a turnover of L389 million for year ending 1994, London Stock Exchange, 1995) the level of critical evaluation of reported accounting numbers is extremely limited. 
In addition, corporate accountants are themselves struggling with new concepts such as asset and liability definition. This has been recognised in the standard setting process in that seven of the standards cover issues not covered by International Standards; these are designed to be 'educational' as well as prescriptive (Garrod and Turk, 1996, pp.154). Laudable though the educational aspect of Slovene standards is, it underlines the problems of any economy which changes its economic goals, aspirations and values over a short period of time. It is unrealistic to expect Slovene company accountants to assimilate these new concepts via accounting standards alone and to be producing 'substance over form' and 'true and fair' accounts immediately. The ongoing debate about asset and liability definitions in the UK, evidenced by the current proposals for a change in goodwill accounting and past debates on brand accounting and intangible assets, indicates the complexity of the problem.

As with accounting standards, the basic model for the role of auditors and their professional regulation has followed the UK/USA model. The developing importance of auditing as the economy itself has changed can be judged by the change in title of the accounting and auditing body(ies) in Slovenija. In the early days of post Second World War Yugoslavia there was the Society of Economists in Slovenija and this dominated academic accounting thinking until the early 1970s when the Society of Accounting Technicians was renamed the Slovene Society of Accountants and Treasurers which subsequently became the Association of Accountants, Treasurers and Auditors. This latter body then established the Slovene Institute of Auditing which now derives further authority from the Law on Auditing and is the parent body of the Slovene Accounting Standards Committee. Despite these institutional developments the comments made above regarding the full appreciation of 'substance over form' and 'true and fair' in the accounting field must, necessarily, limit the effectiveness of the audit process also, even with the development of professional auditing standards and guidelines generated by the Slovene Institute of Auditing. Even in the more developed economies there are clear misgivings about the nature of auditor independence and problems arising from the expectations gap (see e.g. Humphrey et.al., 1992). In an economy where those preparing published accounts may be largely unfamiliar with the concepts behind accounting regulation the loss of effective control can only be exacerbated. In this environment one must question the effectiveness of the external audit process as contributing greatly to the corporate governance structure. 


\section{2 Company Law and Management Structure}

Unlike the accounting and auditing regulations which are largely based on the UK model, company law is heavily influenced by the German commercial code. The relevant section for joint stock companies of the Slovene Law on Commercial Companies is chapter 4 and sections 4 and 5 are the most important from a corporate governance pers pective.

The structure of management must be two tier if the company exceeds certain size limits or is listed (article 261). The supervisory board must comprise at least three members (article 262(1)) with at least one third worker representatives if the company has less than 1,000 employees and one half in companies with more than 1000 employees (Law on W orker Participation in Management, Article 79), the remainder being elected by the shareholders at the annual general meeting (article 264) for companies for a maximum period of four years (article 265). The management board has the responsibility of running the company (article 246(1)) and is appointed for a five year term by the supervisory board (article 250(1)) and must contain at least one worker representative for companies with more than 500 employees Law on W orker Participation in Management, Article 81). This would appear to provide a significant amount of power in the hands of the supervisory board members. However, on close inspection their influence on day to day operating decisions is highly circumscribed, as in the German system. Whilst the scope of the powers of the supervisory board to supervise the conduct of the business and inspect the company's books and documents is clearly established in article 274(1 and 2) it is specifically forbidden in article 274(4) for the supervisory board to manage directly the business.

As described above, this insider system of control depends crucially on cross company shareholdings and bank influence. The ownership structure in Slovenija is quite different to that which pertains in Germany. This will be considered further in the next section but the question of minority interests are particularly relevant to the successful operation of supervisory boards. In Slovenija, ownership is largely concentrated in the hands of worker/manager shareholders and the privatisation investment trusts. In many cases the latter are minority shareholders who are largely disenfranchised due to the concentration of majority shareholders. This significantly reduces the 
power and influence of the supervisory board and allows an effective free hand to internal management and workforce decisions. This negation of control by the nature of ownership structures is well illustrated in article 274(4) which is worth quoting in full:

The management of the business may not be transferred to the supervisory board. The Articles of Association or the supervisory board may determine that certain kinds of transactions shall only be performed with the board's approval. If the supervisory board declines consent, the executive management may request that the matter be referred to the assembly to decide. The approval of the assembly shall be considered to be given if voted for by at least three quarters of all the votes cast.

The logic of the article is that, whilst the supervisory board cannot manage the company, it can force the management board to take a proposal to the owners if the supervisory board disagrees with it. However, the impact of the article is severely restricted when the worker/manager stakeholders and the owner stakeholders largely are one and the same: the power of the supervis ory board is effectively nullified. Recent figures from the Agency of Privatisation indicate that over $70 \%$ of Slovene companies have majority employee ownership which underlines the pervasiveness of the problem.

In Germany the operation of the supervis ory board can be characterised as a form of managerial credit evaluation: managers are screened before being appointed to senior positions, investment plans are discussed before being implemented and the subsequent performance of management and investment is monitored in relation to plans (Franks and Mayer, 1992b). The question that this raises is who should be on the supervisory board to undertake this evaluation. In Germany representatives on the supervisory board come from senior positions in industry and finance in well established firms and institutions, often representatives of the suppliers, purchasers and other related companies that have ownership interests in the firm.

Given the state of economic development in Slovenija there may well currently be insufficient "well established firms and institutions' to provide members to ensure adequate supervisory board control. Carlin and Mayer (1992) document how the Treuhandanstalt has created supervisory boards of east German companies that primarily comprise representatives from west German firms 
and banks. In conjunction with the very different ownership structures prevailing in Slovenija there must be considerable doubt raised about the effective control which the supervisory board structure currently offers in Slovenija.

\section{3 Ownership Structure and Sources of Capital}

The regulatory structure of the Ljubljana Stock Exchange is heavily influenced by the US Securities and Exchange Commission. Whilst the Slovene Securities and Exchange Commission only regulates market operations and not disclosure issues it does have a significant input to the accounting standard setting process. As with accounting regulation the administrative structure is well defined and the regulatory framework extensive and effective as witnessed by the recent action taken against a pyramid investment scheme which threatened the long term viability of the market. Given the thinness of the market itself and the pattern of ownership in Slovenija, however, it must be questioned whether the close monitoring of security market operations flows through to more general corporate governance issues.

Recent work in the field of information asymmetry, agency costs and alternative routes to corporate control and accountability (see e.g. Brennan, 1995) have indicated the subtlety of market operations on influencing management decisions. In this body of work the impact of the relaxation of the ceteris paribus assumptions of the work characterised by Modigliani and Miller (1958) is highlighted. These assumptions restrict analysis to the effect of allocating a given net operating income amongst competing claim holders on the total value of the income stream. In more recent work, however, the effect of the structure of claims on the incentives of the individuals whose decisions determine the income stream itself has been the focus of attention thus highlighting inherent inefficiencies resulting from information asymmetries in the market system.

Brennan (1995) has detailed the potential influences on managers of financing decisions which they take. The analysis of principal agent relationships and information asymmetries between owners and managers have proven most useful in analysing management decisions within the economies which rely on 'external' systems of corporate governance. However, even in the UK these conclusions have to be tempered due to the close relationship between institutional owners and company 
managers. Holland (1995) has identified that the heavy concentration of ownership in a limited number of large financial institutions means that information flows in the UK are less market oriented than is the case in the wider owner base of the US. As a consequence the regulatory aspect of agency relationships is less pronounced. However, the UK institutions are considerable players in the UK securities market and ultimately exert their influence through market operations, unlike the insider model of Germany. Thus the UK can be considered as lying somewhere between the extremes of the US and Germany with regard to the governance influence of the securities markets. In Slovenija, with such a thin and shallow market, market controls on management decisions are likely to be tenuous at best. The nature of the market, in conjunction with current ownership structures, raises significant doubts about the effectiveness of security market operations on governance issues.

A comparison between ownership structures in the US, UK, Germany and Slovenija highlights the significant differences between the three countries (see Table 1).

Table 1

\begin{tabular}{|l|l|l|l|l|}
\hline \multicolumn{5}{|c|}{ Aggregate shareholder ownership of quoted companies } \\
\hline Owner & USA (1994) & UK (1995) & Germany (1995) & Slovenija (1996) \\
\hline Personal & 50.4 & 18 & 17 & 11.9 \\
\hline $\begin{array}{l}\text { Institutions - } \\
\text { excluding banks }\end{array}$ & 43.5 & 61 & 9 & $33.6^{1}$ \\
\hline Banks & n/a & 1 & 10 & n/a \\
\hline Government & n/a & 1 & 6 & n/a \\
\hline Overseas & 5.4 & 16 & 17 & n/a \\
\hline Other companies & n/a & 2 & 42 & n/a \\
\hline Internal & n/a & n/a & n/a & 36.1 \\
\hline
\end{tabular}




\begin{tabular}{|c|l|l|l|l|}
\hline Other & 0.7 & 1 & $\mathrm{n} / \mathrm{a}$ & $18.4^{2}$ \\
\hline Total & $100 \%$ & $100 \%$ & $101 \%$ & $100 \%$ \\
\hline
\end{tabular}

1. Investment, restitution and pension funds

2. Restitution beneficiaries, banks and other creditors, co-operatives, communities, state and foreign physical and legal entities

UK and German source: Stock Exchange Quarterly, 1995

Slovene source: Agency of the Republic of Slovenia for Restructuring and Privatization US source: New York Stock Exchange, 1995.

These figures highlight the major differences in ownership structures between the three countries:

- UK share ownership is dominated by institutional investors

- German share ownership is dominated by cross company holdings

- Slovene share ownership is dominated by internal and institutional investors.

Whilst the German system is often characterised as one which is bank dominated this is clearly not the case in terms of share ownership. Whilst they do normally have representation on the supervis ory board and have effective control over a much larger share holding through proxy vote registration from individual shareholders, it is clearly the cross company holdings which are the predominant descriptors of the system. Stable company share holdings in other companies are driven by commercial rather than investment reasons. This highlights the essentially collaborative nature of the insider system as opposed to the auction system associated with the outsider system.

As identified above, the Slovene situation is characterised by a dominance of internal owners and significant minority holdings by investment funds. Currently $70.9 \%$ of Slovene companies, by number, have majority employee ownership and, even by value the percentage is $34.6 \%$. Of the remaining companies, by value, $49.5 \%$ have employee ownership in the $26-50 \%$ band so that by any measure internal ownership is significant. In this environment the role of the securities market to affect management decisions is severely limited and, as described above, the supervisory role of the two tier management structure is also very much circumscribed. In addition, the lack of any law on 
mergers and acquisitions makes it unclear that takeovers can play any significant role in corporate governance issues.

\section{A Theoretical Model of Corporate Governance Development}

Two useful models for considering the development of corporate governance systems in central and eastern Europe are those of Harris on and McKinnon (1986) and Bailey (1995). Harris on and McKinnon (1986) identify four major as pects of the change process: intrusive events, intra-systems activity, trans-systems activity and cultural environment. The framework is termed as 'modified exogenous' as it incorporates both exogenous and endogenous elements but the former assumes temporal and theoretical precedence. The intrusive events are the exogenous change stimuli which disrupt the system' s pre-existing pattern; intra-systems activity is the interactions amongst the structural elements of the system itself; trans-systems activity is the interactions across system boundaries; and the cultural environment pervades and influences the three other aspects of the system. The visible response to the intrusive event is generated through interactivity among the structural elements of the system (intra- systems activity). The collective and individual responses of the structural elements of the system to change stimuli are circumscribed by the interactions between the system and its neighbouring systems (trans-system activity). This embodies the influence of the nation specific cultural environment which is thereby extended to the response events themselves.

Bailey's model looks more specifically at the accounting change process in the transitional economies of central and eastern Europe. He identifies three stages of development: state directed, state regulated and market driven.

With regard to corporate governance the intrusive event is the change in the economic system itself, the intra systems activity can be thought of as the different aspects of corporate governance systems imported from western countries, the trans-system activity is the relationship between the different aspects of the corporate environment which are as sumed to impact on corporate governance and the cultural environment embodies the historical norms and values of the system itself. 
Utilising Bailey' s model, different aspects of the 'trans-system' corporate governance environment are at different stages of transition. The former Yugoslav version of 'state directed' was the antiStalinist concept of decentralised self-management and social ownership (Kardelj, 1975). At the political level self-management manifested itself in the repudiation of institutions of representative democracy and their replacement by the very complex delegational system of direct democracy. W ith over $70 \%$ of Slovene companies (Agency for Privatisation, 1996) in worker/manager ownership it would appear that ownership structures are still very much in the 'state directed' sector despite the efforts of the Privatisation Agency to broaden ownership in the largest Slovene organisations. Company law and management structure, on the other hand, falls within the "state regulated' zone, via company law whilst accounting, reporting and auditing regulation and security market regulation are firmly located in the market driven area. Accounting and reporting regulation has been assigned to a new autonomous professional body, the Slovene Institute of Auditors, and an independent SEC body has been established to regulate security market operations.

However, these 'intra-systems', which themselves make up the corporate governance environment, display significant market 'inefficiencies'. Accounting regulation and auditing practices are limited in their effectiveness due to their emphasis on investor usefulness and the limited depth and breadth of the securities market; the latter limits the agency consequences of management decisions so that current controls indicated in the financial economics literature emanating from security market operations do not pertain; this is exacerbated by current ownership structures which, in addition, limit the effectiveness of supervisory controls built into existing company law.

Slovenija has a corporate governance environment with the accounting and security market regulation firmly within Bailey's ' market driven' sector whilst it' s accounting and security market practice are still struggling to emulate those of the UK and US, respectively, upon whose regulatory frameworks Slovenija's is modelled. Equally, company law is in the 'state regulated' sector whilst ownership structures still lag behind in the 'state directed' sector. The corporate governance environment appears, therefore, to lag in all three aspects of development to their respective modes of regulation. See Table 2.

\section{Table 2}




\begin{tabular}{|c|c|c|c|}
\hline & State Directed & State Regulated & Market Driven \\
\hline Intrusive Event & $\begin{array}{c}\text { Change of economic and } \\
\text { political system }\end{array}$ & & \\
\hline $\begin{array}{c}\text { Intra-System Activity } \\
\text { Accounting, Reporting and } \\
\text { Auditing Regulation } \\
\text { Company Law } \\
\text { Security Market Regulation }\end{array}$ & & Commercial Code & $\begin{array}{l}\text { Autonomous accounting } \\
\text { profession } \\
\text { Autonomous regulatory } \\
\text { body }\end{array}$ \\
\hline $\begin{array}{c}\text { Trans-System Activity } \\
\text { Accounting, Reporting and } \\
\text { Auditing Environment } \\
\text { Company Law Environment } \\
\text { Security Market Environment }\end{array}$ & $\begin{array}{c}\text { Ownership structures } \\
\text { resulting from privatisation } \\
\text { process }\end{array}$ & $\begin{array}{l}\text { Limited understanding of } \\
\text { investor needs driven reports } \\
\text { Limited equity market with } \\
\text { thin trading }\end{array}$ & \\
\hline Cultural Environment & $\begin{array}{l}\text { Self management sustained } \\
\text { through privatisation } \\
\text { process }\end{array}$ & Belief in regulatory process & $\begin{array}{l}\text { 'entrepreneurs' still } \\
\text { regarded with some } \\
\text { suspicion }\end{array}$ \\
\hline
\end{tabular}

If this situation occurs in other transition economies then the effectiveness of importing corporate governance regulations from other economic environments seems limited. The economics of transition has borrowed heavily from the problematic of transition from sociology (Stark, 1996). However, the transition of the former command economies to a well known and well tried system of the market economy is different from the unknown change of the sociology literature. As in all versions of modernisation theory, transitology, as this new science is known, begins with a future that is not only desired but already known. But do we know what a market economy is? As illustrated above many aspects of the historically market based economies are unique and culturally based. Likewise with the former command economies. It therefore seems likely that the eventual 'market' economies of the transitional economies will display the same level of diversity. 
In this case the importation of market driven regulations which depend upon their own unique environments to be effective into an environment of rapid change and development is not helpful. Bailey's state regulated stage of development would appear to be under utilised in the transitional economies where the politicians' zeal in trying to achieve 'market' economy acceptance and respectability has not maintained the crucial link between regulation, institutions and environment.

For market driven regulation to become more effective, securities markets need to become wider and deeper so traditional agency constraints will become effective controls on management decisions. This implies not only that the number of traded equity securities has to grow substantially but, more critically, that the nature of share ownership becomes more dispersed and fluid. It is unclear that this is necessarily a desirable or beneficial development at the current state of economic development in the region. If more companies are encouraged to undertake a public flotation then political rather than financial factors (see e.g. Byrne and Rees, 1994) will be driving the decision and will not, necessarily, be to the benefit of the companies involved. If trading is to increase then existing, largely small, shareholders must be encouraged to come to the market. W ith a recent cultural history in the economies of central and eastern Europe towards high propensities to consume and low propensities to save it is likely that only sales will occur, thus further undermining the development and confidence in the market.

In addition, cultural history would suggest that the accounting professions in the region are used to a legalistic definition of accounting practice (Bailey, 1995) and as the transitional market economy is underdeveloped, there is only a formal compliance with the requirements of the accounting reform. This suggests that the information requirements of fully operating securities markets will be inadequately served by existing practice and that commercially neces sary accounting changes will lag the legally specified accounting regulation.

For state regulation to become effective in the governance field, institutions like banks or some government agency must become more actively involved in the supervisory role of companies. This would require a significant development on the part of banks in their commercial expertise and the role which they currently play in economic development. As bad loans of the past are gradually 
eliminated from their balance sheets it is likely that bank financing will play an increasingly important part in capital growth for companies in the region. This would act as a platform for greater participation of banks in the governance role. In the short term this role might be more effectively played by a government agency of some kind. All countries in the region have some mechanism for co-ordinating the privatisation of economic units within their economies and, by definition, these agencies are of finite life. Given their intimate knowledge of the companies privatised they could well play an useful role in the supervisory function post privatisation.

Such a development would have significant implications for the speed and nature of the development of the securities markets. If banks developed in this supervisory way then the whole corporate environment would move inexorably towards the insider, or German, model. In this case securities markets are unlikely to develop into the deep and broad markets of the USA or UK. This would imply that accounting and auditing regulation as currently conceived would never play an effective role in the practical application of corporate governance in the region. If this latter development is desired then careful nurturing via Bailey's state regulation mechanisms would be called for.

\section{Concluding Remarks}

The wide diversity of corporate governance models in the historical market economies raises an important question for the emerging market economies of central and eastern Europe as to which model they should adopt. Given that these distinct methods of corporate governance have developed, and work, due to the historical development of management, ownership and regulatory systems in the different countries it is unlikely that any one system will work adequately within the emerging economies. Equally a 'patchwork' approach of drawing from multiple systems may lead to unforeseen gaps in the control mechanism as has been suggested in the case of Slovenija.

In the discussion above a very wide perspective of corporate governance has been adopted which incorporates three major strands:

1. accounting, reporting and auditing regulation

2. company law and management structure

3. ownership structure, sources of capital and security market operations. 
A mis match between regulations affecting corporate governance and the institutional requirements for their effective operation has been identified. Using the intrusive event model of Harrison and Mackinnon and Bailey's accounting transition model, the need for nurturing governmental regulation to achieve an effective and sustainable corporate governance environment in the transitional economies has been identified. Rather than aiming at a static governance environment which will be suitable when the transitional economies 'achieve' transition it allows for dynamic development such that effective governance can be achieved at all stages of the change process. Under current regulations it is paradoxical that privatis ation schemes modelled on a broadly held outsider system have created the circumstances in which only the insider system appears to offer a workable structure for corporate governance in the short and medium term. 


\section{REFERENCES:}

Accounting and Business Research, 1993; Corporate Governance Special Is sue

Alchian, A. and H. Demsetz, 1972; Production, Information Costs and Economic Organization; American Economic Review; Vol. 62; pp. 777-795.

Bailey, D., 1995; Accounting in Transition in the Transitional Economy; European Accounting Revue; Vol.4 No.4; pp. 595 - 624

Baums, T., 1993; Takeovers Versus Institutions in Corporate Governance in Germany; in Prentice, D.D. and P.R.J. Holland (eds); Contemporary Issues in Corporate Governance; Clarendon Press, Oxford.

Birnberg, J.G., L. Turpolec and S.M. Young, 1983; The Organizational Context of Accounting; Accounting, Organizations and Society; Vol. 8; pp. 111-130.

Berle, A. and G. Means, 1932; The Modern Corporation and Private Property; New York; MacMillan.

Brennan, M., 1995; Corporate Finance Over the Past 25 Years; Financial Management; Vol. 24, No. 2, Summer; pp.9-22.

Byrne, A. and W. Rees, 1994; Initial Public Offerings in the United Kingdom, ACCA Research Report 36, pp.45.

The Cadbury Report, 1992; Financial Aspects of Corporate Governance; London.

Cadbury, A., 1993; Reflections on Corporate Governance; The Chartered Institute of Bankers, London.

Carlin, W. and C. Mayer, 1992; The Treuhandanstalt: State versus Markets; in Froot, K. and J. Sachs (eds); Economic Reform in Eastern Europe; National Bureau of Economic Research, Chicago.

Companies Act; 1985; HMSO, London.

Companies Act; 1989; HMSO, London.

Dimsdale, N., 1994; The Need to Restore Corporate Accountability: An Agenda for Reform Postscript on the Draft Report of the Cadbury Committee; in Dimsdale, N. and M. Prevezer (eds.), 1994; Capital Markets and Corporate Governance; Clarendon Press, Oxford.

Economist, 1994; Corporate Governance; 29 January. 
Fama, E. and M. Jensen, 1983; Agency Problems and Residual Claims; Journal of Law and Economics; Vol. 26; pp. 327-349.

Franks, J.R. and C. Mayer, 1992a; Hostile Takeovers and the Correction of Managerial Failure; London Business School Discussion Paper.

Franks, J.R. and C. Mayer, 1992b; Corporate Control: A Synthesis of the International Evidence; IFA Working Paper 165-92; London Business School.

Franks, J.R. and C. Mayer, 1996; Ownership, Control and the Performance of German Corporations; Working Paper as part of the ESRC funded project on Capital Markets, Corporate Governance and the Market for Corporate Control.

Garrod, N. and I. Turk, 1996; The Adaptation of International Accounting Rules: Lessons from Slovenia; in Garrod and McLeay (eds), 1996; Accounting in Transition; Routledge, London

Govindarajan, V. and A.K. Gupta, 1985; Linking Control Systems to Business Unit Strategy: Impact on Performance; Accounting, Organizations and Society; Vol. 10 No.1; pp. 51-66.

Harrison, G.L. and J.L. McKinnon, 1986; Culture and Accounting change: A New Perspective on Corporate Reporting Regulation and Accounting Policy Formulations; Accounting, Organizations and Society; Vol. 11, No.3 pp. 233-252.

Holland, John, 1995; The Corporate Governance Role of Financial Institutions in their Investee Companies; ACCA Research Report 46.

Holland, John, 1996; Economic Incentives for the Self-Regulation of the Release of Price-Sensitive Information; European Journal of Law and Economics ; Vol. 3, pp. 221-247.

Humphrey, C., P. Moizer and S. Turley, 1992; Auditing Expectations Gap - Plus ca Change, Plus c'est la Meme Chose?; Critical Perspectives on Accounting; Vol. 2, pp. 137-162.

Jenkinson, T. and C. Mayer, 1992; Hostile Takeovers; MacMillan, London.

Johns on, H.T. and R.S. Kaplan, 1987; Relevance Lost: The Rise and Fall of Management Accounting; Harvard Business School Press, Boson, Massachusetts.

Kardelj, E., 1975; Samoupravljanje. Ena Izmed Zakonitosti v Razvoju Socializma; Teorija in Prakska; Vol. 12 (10); pp. 947-954.

Lawrence, M., 1994; Corporate Governance, Coopers and Lybrand Lecture, University of Wales, Aberystwyth.

London Stock Exchange; 1995; Stock Exchange Quarterly; Summer; London. 
London Stock Exchange; 1997; Stock Exchange Fact File; London.

Manne, H., 1965; Mergers and the Market for Corporate Control; Journal of Political Economy; pp. 110-120.

Modigliani, F. and M.H. Miller, 1958; The Cost of Capital, Corporation Finance and the Theory of Investment; American Economic Review, Vol. 48; pp. 261-297.

Monks, Robert A.G. and Neil Minow, 1995; Corporate Governance; Blackwell.

New York Stock Exchange, 1995; Shareownership; New York Stock Exchange Inc, New York.

Ordelheide, D. and D. Pfaff, 1994; European Financial Reporting: Germany; Routledge, London.

Puxty, A.G., H.C. W ilmott, D.J. Cooper and A.E. Lowe; 1987; Modes of regulation in Adevanced Capitalism: Locating Accountancy in Four Countries; Accounting, Organizations and Society; Vol.12, No.3; pp. 273-291.

Scharfstein, D., 1988; The Disciplinary Role of Takeovers; Review of Economic Studies; Vol. 55; pp. 85-99.

Sheikh, S. and W. Rees, 1995; Corporate Governance and Corporate Control; Cavendish Publishing.

Sheikh, S. and S.K. Chatterjee, 1995; Perspectives on Corporate Governance; in Sheikh, S. and W, Rees, 1995; Corporate Governance and Corporate Control; Cavendish Publishing.

Smith, T., 1996; Accounting for Growth; Century Business Books, 2nd. Edition.

Stark, D., 1996; Network of Assets, Chain s of Debt; in Corporate Governance in Central Europe and Russia; CEU Press, Budapest.

Streek, W . and P.C. Schmitter, 1985; Community, Market, State - and As sociations; in Streek, W . and P.C. Schmitter (eds); Private Interest Government and Public Policy, Sage, London.

Tricker, R.J., 1984; Corporate Governance: Practices, Procedures and Powers in British Companies and Their Boards of Directors; Gower.

Tricker, R.I., 1993; Editorial; Journal of Corporate Governance; Vol. 1 No. 1, pp. 1-3.

Vasilev, D., 1996; Corporate Governance in Russia: 1994-1995; Central and Eastern European Privatization Network Newsletter; Nos. 6/7; pp. 7- 13. 